\title{
Perangkat Pembelajaran (RPS dan SAP) IPA Model (OPPEMEI) untuk Meningkatkan Keterampilan Berpikir Kreatif Mahasiswa PGSD
}

\author{
*I Gusti Ayu Tri Agustiana1, Rudiana Agustini², Musimin Ibrahim³ , I Nyoman Tika4
}

${ }^{1}$ Prodi Pendidikan Guru Sekolah Dasar (PGSD), FIP, Universitas Pendidikan Ganesha, Indonesia

${ }^{2}$ Chemistry Education of Department, State University of Surabaya, Indonesia

${ }^{3}$ Biology Education of Department, Stat University of Surabaya, Indonesia

${ }^{4}$ Program Studi penidikan Dasr Pasca Sarjana Unidksha, Indonesia

\section{A R T I C L E I N F O}

Article history:

1 Maret 2020 Received in revised form

30 Maret 2020

Accepted 11 April 2020

Available online 15

Mei 2020

Kata Kunci:

Perangkat pembelajaran OPPEMEI

Berfikir Kreatif

Keywords: learning tools, OPPEMEI, creative thinking

\begin{abstract}
A B S T RA K
Penelitian ini bertujuan untuk menganalisis kebutuhan perangkat pembelajaran, mengembangkan perangkat pembelajaran, dari MODEL OPPEMEI. Seluruh data diperoleh dari instrumen pengumpulan data dan dianalisis secara deskriptif tentang validitas dan reliabilitas terhadap hasil produk pengembangan RPS dan SAP yang terdiri dari 4 topik ) untuk mata kuliah konsep dasar IPA yang di nilai oleh Ahli dalam bidang pendidikan IPA dan Dosen pengampu mata kuliah konsep dasar IPA. Hasil penelitian ini menunjukkan bahwa: (1) Kriteria validitas komponen-komponen RPS secara umum sangat valid. Koefisien reliabilitas percentage of agreement lebih dari $80 \%$, (94\%) sehingga tingkat konsistensi antar ahli terhadap keseluruhan aspek validitas konstruk model OPPEMEI sangat tinggi. Hasil analisis validitas RPS menunjukkan ahli sepakat bahwa RPS yang telah dikembangkan berdasarkan model OPPEMEI telah dikonstruksi secara logis dan
\end{abstract} konsisten, sehingga RPS secara substansi dinilai layak untuk mendukung implementasi model OPPEMEI. (2) kriteria validitas komponen-komponen SAP Model OPPEMEl secara umum sangat valid. Koefisien reliabilitas untuk topik I, II, III dan IV, berturut-turut 0 , 89; 93; 0,93, dan 0,89 sehingga tingkat konsistensi antar ahli terhadap keseluruhan komponen SAP-Model OPPEMEI sangat tinggi. Hal tersebut mengindikasikan ahli sepakat bahwa SAP-Model OPPEMEI yang telah dikembangkan layak sebagai pendukung implementasi model OPPEMEI.

\section{A B S T R A C T}

The aim of this research was to analyze the needs of learning tools and to develop the learning tools of OPPEMEI MODEL. All data were collected by using data collection instruments and it analyzed descriptively. The validity and reliability on the development of RPS and SAP were consisted of 4 topics on the basic natural science concept course and it assessed by experts in the field of natural science education. The results of this research showed that: (1) the validity criteria for RPS components were generally very valid. The reliability coefficient percentage of agreement was more than $80 \%$, (94\%) so that the level of consistency among experts on all aspects of the construct validity of the OPPEMEI model was very high. The results of the analysis showed that the development of RPS based on the OPPEMEI model had been constructed logically and consistently, so that the RPS was feasible to support the implementation of the OPPEMEI model. (2) the validity criteria of SAP components on the OPPEMEI Model were generally very valid. Reliability coefficients for topic I, II, III and IV were 0.89; 93; 0.93 and 0.89 so that the level of consistency among experts on all components on SAP-Model OPPEMEI was very high. This result showed that the SAP-OPPEMEI model was feasible to support the implementation of OPPEMEI model.

Copyright (C) Universitas Pendidikan Ganesha. All rights reserved

Corresponding author

E-mail addresses: triagustiana.pgsdundiksha@gmail.com (Tri Agustina) ${ }^{1}$, rudiana.agustini@gmail.com (Rudiana) ${ }^{2}$

muslimin.ibr@gmail.com (Musimin)33 nyomanntika@gmail.com (Tika) ${ }^{1}$ 


\section{Pendahuluan}

Zaman globalisasi merupakan proses mendunia di mana individu tidak terikat oleh negara atau batas-batas wilayah, sehingga membangun lulusan yang memiliki keterampilan sangat dibutuhkan. Kondisi ini ditandai oleh perkembangan teknologi informasi dan komunikasi yang sangat pesat, sehingga berubah menjadi tatanan komunitas global. Sehingga dibutuhkan model pembelajaran yang dapat meningkatkan keterampilan berpikir kreatif mahasiswa, khususnya dalam pembelajaran IPA. Sesuai dengan teori perkembangan kognitif Piaget, keterampilan berpikir kreatif dapat diadaptasikan di kelaskelas awal perkembangan pengetahuan anak. Intervensi untuk mentransformasi IPA di SD, adalah pembenahan pada mahasiswa calon guru. Kajian ini ditunjang oleh hasil belajar IPA siswa-siswa SD relatif rendah. Data ini ditunjang hasil belajar IPA di SD 1 dan 2 Kaliuntu, Kecamatan Buleleng, Kabupaten Buleleng, Provinsi Bali (Agustiana, 2009). Hal ini juga nampak dari hasil ulangan harian semester I pada mata pelajaran IPA kelas IV di SDN 2 Srandakan Kecamatan Srandakan Kabupaten Bantul tergolong masih rendah. Rendahnya hasil belajar pada pembelajaran IPA ini disebabkan oleh beberapa faktor, diantaranya adalah penggunaan metode guru mengajar yang kurang tepat, sehingga siswa hanya menghafal bukan memahami materi (Purwandari, dkk., 2013) Pemahaman terhadap IPA yang rendah, juga diakibatkan pada kemampuan berpikir kreatif anak (Fauziah, 2011). Bila dilihat dari kompetensi keterampilan berpikir kreatif (creative thinking) memiliki ciri-ciri sebagai berikut: (1) ulet mengerjakan tugas-tugas, (2) menyadari keterbatasan pengetahuan dan kemampuan dirinya, (3) memiliki standar pribadi untuk dicapai dalam belajar, dan (4) membangkitkan cara-cara baru untuk mencapai standar. Kondisi ini berkaitan dengan guru sebagai model belajar (Tan, 2003). Guru harus mampu mengembangkan nalar ilmiah siswa sehingga dapat meningkatkan pemahaman konten materi IPA dan kemampuan berpikir kreatif siswa, terbukti indeks pembangunan pendidikan Indonesia relatif ketinggalan dari negara lain (OECD, 2013).

Nalar ilmiah dapat dibangun dengan pendidikan IPA. Fondasi yang kokoh dalam pendidikan IPA untuk meningkatkan pemahaman IPA di SD adalah pada optimalisasi pendidikan IPA pada calon guru SD, yaitu pada mahasiswa PGSD. Dimensi pendidikan IPA di PGSD adalah konsep dasar IPA. Konsep dasar IPA merupakan materi IPA yang relevan untuk pemahaman konsep anak-anak SD. Namun pendidikan IPA di SD belum sepenuhnya optimal. Lebih dari 45\%, mahasiswa PGSD Undiksha miskonsepsi tentang beberapa konsep IPA (Laksana, 2016). Motivasi mempelajari IPA di PGSD juga relatif rendah (Maryani \& Martiningsih, 2015). Pada aspek keterampilan berpikir kreatif pun juga masih rendah pada pengajaran mahasiswa PGSD. Hal ini didukung oleh rata-rata hasil test berpikir kreatif pada sebelum dan sesudah perlakuan untuk mahasiswa PGSD Undiksha untuk pembelajaran IPA sebelum perlakuan dengan menerapkan model OPEMES rata-rata hasil test berpikir kreatif adalah sebanyak 58,50, sementara setelah perlakuan dengan menerapkan model OPEMES rata-rata hasil test berpikir kreatif adalah sebanyak 70,68 (Agustiana, 2015). Rendahnya keterampilan berpikir kreatif berkorelasi dengan pendidikan IPA pada mahasiswa calon guru SD (Pamungkas, 2017 ; Sulistyaningrum, Winata, \& Cacik, 2019).

Keterampilan guru-guru IPA, seyogyanya dibangun lebih awal pada mahasiswa calon guru IPA SD. Oleh karena itu, berbagai upaya ahli pendidikan telah dilakukan untuk membangun keterampilan berpikir kreatif, yaitu menggunakan pengajaran IPA di SD lewat model Project Vidio Class, Inquiry Based Science Model (IBSEM) (Suhandi, Samsudin, \& Hermita, 2018). Pembelajaran IPA secara empiris, diupayakan untuk meningkatkan kreativitas pada mahasiswa calon guru SD (PGSD) telah dilakukan oleh beberapa peneliti. Fazilla (2016) menemukan juga bahwa jika mahasiswa PGSD diberikan LKS IPA, maka mahasiswa mudah membaca dan mampu menyerap pesan yang terkandung dalam lembar kerja, dengan tingkat keterlaksanaan dan tingkat keternilaiannya tinggi. Rustaman (2005) menunjukkan bahwa pembelajaran sains akan efektif kalau makna dan manfaat pembelajaran IPA dipahami dengan benar.

Pengajaran IPA untuk mahasiswa PGSD mengacu pada kompetensi lulusan, belum optimal dilaksanakan (Laksana, 2016). Hal ini disebabkan oleh perangkat pembelajaran seperti Silabus, SAP dan bahan ajar untuk perkuliahan IPA dasar yang belum memberikan peluang untuk munculnya keterampilan berpikir kreatif. Kekurangan aspek berpikir kreatif berakibat pada motivasi mahasiswa belajar (Fauziah, 2011). Kondisi lain, penggunaan metode pembelajaran berbasis masalah dengan menggunakan permasalahan yang tidak sesuai dengan lingkungan tempat belajar peserta didik, mengakibatkan berpengaruh terhadap intelegensi individual peserta didik (Talib \& Kailani, 2014). Pendekatan inkuiri dalam pembelajaran IPA yang kurang menekankan advace manager (suatu rencana pembelajaran yang digunakan untuk menguatkan konsep-konsep informasi yang baru), disebabkan karena tidak dapat menerapkan kemampuan pencarian ide/gagasan pada peserta didik, sehingga keterampilan berpikir kreatif dan hasil belajar peserta didik rendah (Rahayu, Susantini, \& Asmara, 2015).

Peningkatan keterampilan berpikir kreatif mahasiswa jurusan PGSD adala kemampuan untuk pemberian orientasi, penggalian ide kreatif dan penyajian karya, yang semua itu menjadi tangga-tangga 
motivasi untuk meningkatkan berpikir kreatif mahasiswa. Kondisi ini membenarkan dikuatkan oleh teori kognitif, yang memberikan perspektif tentang motivasi manusia (Arends, 2012). Hal lain juga diberikan penguatan dengan Teori atribusi dari Bernard Weiner, yaitu pada teori kognitivis besar, dan teori atribusi, ternyata bagi calon guru untuk memberikan bahwa memahami dan menafsirkan penyebab keberhasilan atau kekeliruan dalam menyajikan ide kreatif dan karya-karyanya hasil pemikirannya, berpengaruh pada motivasi peserta didik (Arends, 2012).

Pembekalan kepada calon guru SD yang mengajarkan IPA, harus mampu memetakan kognisi pada ranah ontology dan epistemology dari tubuh elemen-elemen yang membangun kekuatan pada pendidikan IPA. Ada beberapa pemaknaan IPA sebagai kajian gejala-gejala alam, seperti Samatowa (2006), menulis bahwa, IPA membahas tentang gejala-gejala alam yang disusun secara sistematis berdasarkan hasil percobaan dan pengamatan yang dilakukan oleh manusia. Gie (2003) memberi batasan bahwa berpikir kreatif adalah suatu rangkaian tindakan yang dilakukan orang dengan menggunakan akal budinya untuk menciptakan buah pikiran baru dari kumpulan ingatan yang berisi ide, keterangan, konsep, pengalaman, dan pengetahuan. Pengertian ini menunjukkan bahwa berpikir kreatif ditandai dengan penciptaan sesuatu yang baru dari hasil berbagai ide, keterangan, konsep, pengalaman, maupun pengetahuan yang ada dalam pikirannya. Model pembelajaran untuk mengembangkan keterampilan berpikir kreatif untuk mengajarkan konsep dasar IPA antara lain; (1) model pembelajaran problem based learning (Connell, 2009; Jones, 2006; Zhang, Wang, \& Wang, 2016; McParland M, Noble LM, 2004; Graaff \& Kolmos, 2003; Lam, 2004), (2) model brain based learning (BBL) (Weiss, 2000: 28; Caine \& G, 1945; Osgood-Campbell, 2015), (3) model inkuiri (Acar dan Paton: Katchevich, et al., 2013; Mahgoub, et al., 2014; Mastropieri, Margo, Thomas, \& Carter, 2001; Holaday \& Buckley, 2008).

Berdasarkan analisis model-model pembelajaran yang digunakan untuk meningkatkan keterampilan berpikir kreatif, sehingga pada tahap awal pembalajaran perlu dilakukan pembenahan sesuai dengan produk belajar yang yang diharapkan. Kondisi demikian, peserta didik dituntut, mampu memodifikasi dan melakukan pembenahan titik fokus perhatian (orientasi). Kondisi ini memberikan fase pengenalan awal lewat pengetahuan yang dimiliki peserta didik. Dengan menggunakan kemampuan awal dari fase orientasi, selanjutnya perlu ditekankan pada penggalian ide-ide yang menantang kognitif mahasiswa. Tiap-tiap mahasiswa atau peserta didik akan memiliki berbagai macam ide, penyelidikan untuk pemecahan masalah kreatif dan perlu juga dilakukan saling tukar menukar ide (elaborasi). Fase elaborasi ini, aspek mengembangkan dan hasil karya menjadi perlu dilakukan. Saat presentasi produk hasil belajar ini dosen melakukan evaluasi, negosiasi, refleksi, serta revisi dan terakhir perlu dilakukan implementasi yang merupakan integrasi dan penghargaan terhadap hasil karya cipta mahasiswa. Prinsipprinsip itu sentuhan baru dalam pembelajaran IPA, khusus IPA dasar bagi mahasiswa calon guru yaitu model yang mampu memberikan sentuhan lebih spesifik pada berpikir kreatif, model yang digunakan adalah model pembelajaran OPPEMEI, model ini memiliki sintak sebagai berikut (1) orientasi, (2) penggalian ide kreatif, (3) penyelidikan (investigasi), (4) elaborasi, (5) mengembangkan dan menyajikan hasil karya, (6) evaluasi proses produk, dan (7) implementasi. Penggunaan model ini berangkat dari teori motivasi kognisi, teori ini percaya bahwa individu terdorong untuk melaksanakan tindakan dari pemikirannya. Teori atribusi, menurut (Arends, 2012), adalah cara individu memahami dan menafsirkan penyebab keberhasilan atau kegagalan dapat menjadikannya sebagai motivasi.

Berdasarkan teori belajar tersebut model OPPEMEI ini pada prinsipnya dapat meningkatkan keterampilan berpikir kreatif dan hasil belajar kognitif mahasiswa dalam mempelajari IPA. Pembelajaran IPA melibatkan peran tindakan nyata, yakni dalam pembelajaran harus dilakukan melalui kegiatan nyata dengan praktek atau pengalaman langsung. Ilmu Pengetahuan Alam (IPA) merupakan salah satu mata kuliah wajib diikuti pada mahasiswa calon guru untuk sekolah dasar. Mahasiswa dengan pembelajaran IPA di kelas, diharapkan mengenal tentang diri sendiri serta lingkungan sekitarnya sehingga idealnya pembelajaran IPA harus membelajarkan mahasiswa untuk memperoleh produk dan proses, serta secara tidak langsung dapat membentuk keterampilan berpikir kreatif mahasiswa.

Ketiga model pembelajaran ini saling melengkapi. Aspek yang dapat diekstrak dari kelebihan model-model itu, yakni: motivasi, penggalian ide kreatif dari masalah yang diberikan, penyelidikan atau observasi, elaborasi, menghasilkan dan menyajikan hasil karya, evaluasi proses dan produk dan implementasi konsep yang telah menguat sebagai bentuk internalisasi pengetahuan (OPPEMEI). Menurut Munandar (2009) ciri kemampuan berpikir kreatif yaitu kelancaran (fluency), keluwesan (flexibility), keaslian (originality), merinci (elaboration) dan menilai (evaluation).

Oleh karena itu, penyusunan perangkat pembelajaran perlu dikembangkan yaitu, RPS dan SAP, sehingga perludlakukan penelitian terhadap validitas dan realibilitas perangkat yang telah disusun 
sehingga tujuan untuk dapat menghasilkan meningkatkan kemampuan berpikir kreatif mahasiswa PGSD bisa diharapkan.

\section{Metode}

Jenis penelitian ini adalah penelitian pengembangan yang bertujuan untuk mengembangkan prangkat pembelajaran denan model pembelajaran OPPEMEI yang dapat meningkatkan keterampilan berpikir kreatif. Desain penelitiannya sebagai berikut. Subyek penelitian dalam adalah 60 mahasiswa Jurusan pendidikan PGSD Undiksha yang memprogram Matakuliah Konsep dasar IPA. Penelitian dilaksanakan pada bulan Januari sampai Desember 2017. Secara lebih lengkap tahap pengembangan model pembelajaran OPPEMEI ini digambarkan pada gambar 01 berikut serta gambaran penelitian ditunukkan pada tabel 01. Untuk instrument yang digunakan untuk mengumpulkan data akan dijabarkan pada tabel 02 berikut.

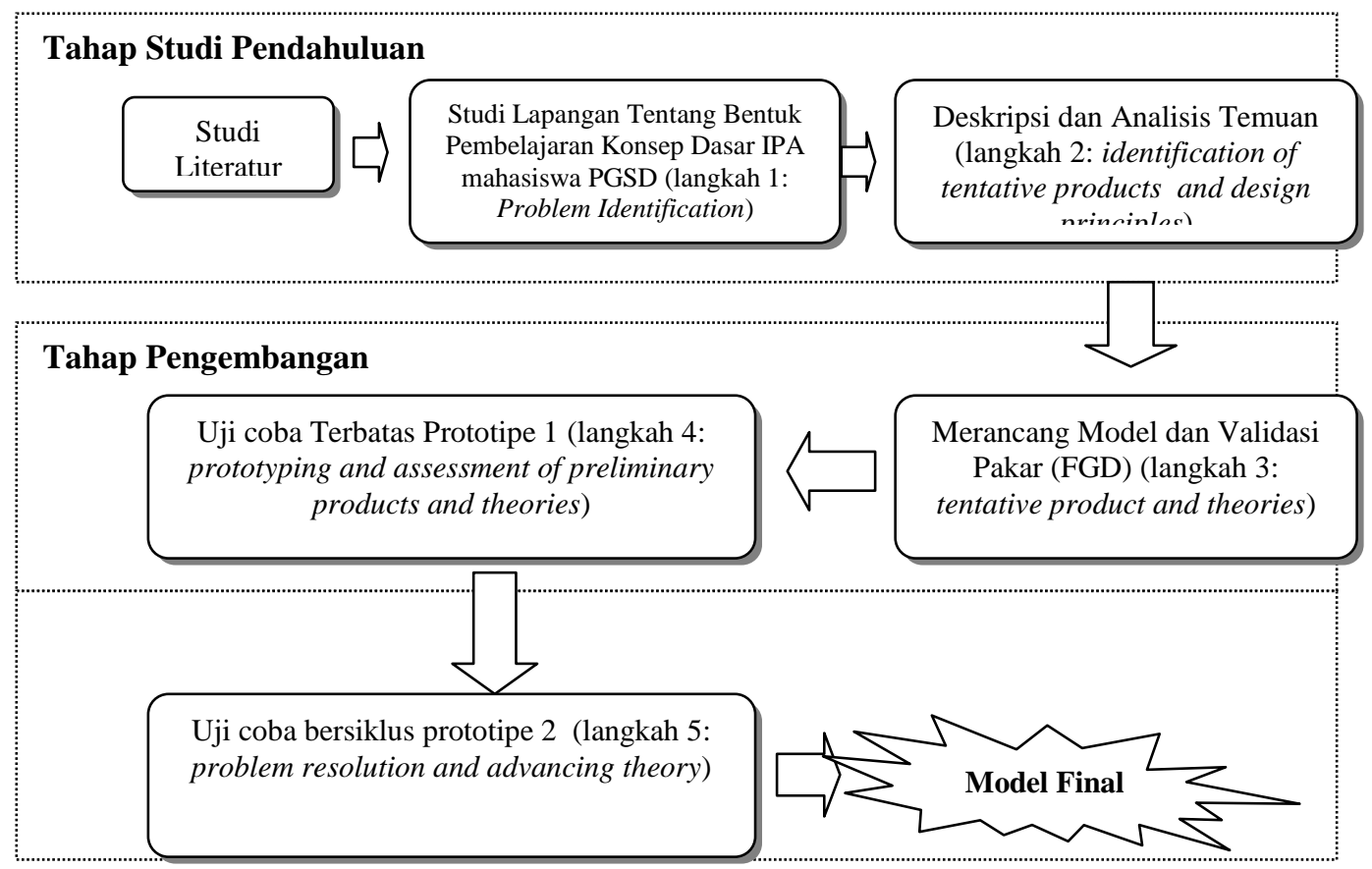

Gambar 01

Tahapan penelitian

Tabel 01. Bagan Penelitian

\begin{tabular}{|c|c|c|c|}
\hline Kegiatan & $\begin{array}{l}\text { Luaran } \\
\quad \text { Prelimena }\end{array}$ & $\begin{array}{l}\text { Lokasi } \\
\text { y research }\end{array}$ & Indikator \\
\hline a. Kajian literatur & $\begin{array}{l}\text { Deskripsi pola } \\
\text { pembelajaran yang } \\
\text { dianggap ideal }\end{array}$ & $\begin{array}{l}\text { Surabaya } \\
\text { Singaraja, Bali }\end{array}$ & $\begin{array}{l}\text { Mendapatkan } \\
\text { informasi kebutuhan } \\
\text { dan keterbaruan akan } \\
\text { pengembangan model }\end{array}$ \\
\hline $\begin{array}{l}\text { b. Studi lapangan } \\
\text { tentang } \\
\text { pembelajaran IPA }\end{array}$ & $\begin{array}{l}\text { Teridentifikasi } \\
\text { masalah keterampilan } \\
\text { berpikir kreatif dalam } \\
\text { pembelajaran IPA }\end{array}$ & Singaraja, Bali & $\begin{array}{l}\text { Data hasil penelitian } \\
\text { keterampilan berpikir } \\
\text { kreatif mahasiswa } \\
\text { sesuai indikator }\end{array}$ \\
\hline $\begin{array}{l}\text { c. Mengembangkan } \\
\text { kerangka } \\
\text { konseptual dan } \\
\text { teoritis penelitian }\end{array}$ & $\begin{array}{l}\text { Gambaran kerangka } \\
\text { konseptual dan teoritis } \\
\text { penelitian }\end{array}$ & Surabaya & $\begin{array}{l}\text { Mendapatkan } \\
\text { kerangka } \\
\text { pengembangan Buku } \\
\text { Model Hipotetik } \\
\text { OPPEMEI, perangkat } \\
\text { dan instrumen } \\
\text { penunjang }\end{array}$ \\
\hline
\end{tabular}




\begin{tabular}{|c|c|c|c|}
\hline \multicolumn{4}{|l|}{ Prototipe stage } \\
\hline $\begin{array}{l}\text { a. Merancang } \\
\text { prototipe }\end{array}$ & $\begin{array}{l}\text { Prototipe I (Model } \\
\text { Hipotetik OPPEMEI,, } \\
\text { perangkat dan } \\
\text { instrumen penunjang) }\end{array}$ & Surabaya & $\begin{array}{l}\text { Buku Model Hipotetik } \\
\text { OPPEMEI,, perangkat } \\
\text { dan instrumen } \\
\text { penunjang }\end{array}$ \\
\hline b. Validasi prototipe & $\begin{array}{l}\text { Prototipe II (Model } \\
\text { Hipotetik OPPEMEI, } \\
\text { perangkat dan } \\
\text { instrumen penunjang) } \\
\text { yang memenuhi } \\
\text { validitas isi dan } \\
\text { validitas konstruk }\end{array}$ & Surabaya & $\begin{array}{l}\text { Dihasilkan prototipe II } \\
\text { berupa Model } \\
\text { Hipotetik OPPEMEI } \\
\text { yang divalidasi pakar } \\
\text { dan praktisi melalui } \\
\text { FGD }\end{array}$ \\
\hline c. Ujicoba penelitian & $\begin{array}{l}\text { Prototipe III (Model } \\
\text { Hipotetik OPPEMEI, } \\
\text { perangkat dan } \\
\text { instrumen penunjang) } \\
\text { yang praktis dan } \\
\text { efektif }\end{array}$ & Singaraja, Bali & $\begin{array}{l}\text { Diperoleh data hasil } \\
\text { penelitian tentang } \\
\text { kepraktisan dan } \\
\text { keefektifan Model } \\
\text { Hipotetik OPPEMEI } \\
\text { beserta perangkat dan } \\
\text { instrument } \\
\text { penunjangnya }\end{array}$ \\
\hline \multicolumn{4}{|l|}{ Assesment Phase } \\
\hline Ujicoba bersiklus & $\begin{array}{l}\text { Prototipe IV/Final } \\
\text { (Model } \\
\text { OPPEMEI Perangkat } \\
\text { dan Instrumen } \\
\text { penunjang) yang } \\
\text { praktis dan efektif }\end{array}$ & Singaraja, Bali & $\begin{array}{l}\text { Diperoleh data hasil } \\
\text { penelitian tentang } \\
\text { kepraktisan dan } \\
\text { keefektifan Model } \\
\text { OPPEMEI beserta } \\
\text { perangkat dan } \\
\text { instrumen } \\
\text { penunjangnya } \\
\text { sehingga mendapatkan } \\
\text { prototipe final }\end{array}$ \\
\hline $\begin{array}{l}\text { Analisis data hasil } \\
\text { ujicoba }\end{array}$ & $\begin{array}{l}\text { Hasil analisis data, } \\
\text { penyusunan } \\
\text { kesimpulan } \\
\text { berdasarkan hasil } \\
\text { diskusi dalam laporan } \\
\text { dan temuan teori. }\end{array}$ & $\begin{array}{l}\text { Singaraja, Bali } \\
\text { Surabaya }\end{array}$ & Laporan analisis data \\
\hline $\begin{array}{l}\text { Menyusun laporan dan } \\
\text { penggandaan untuk uji } \\
\text { kelayakan }\end{array}$ & Laporan hasil ujicoba & Surabaya & $\begin{array}{l}\text { Laporan hasil ujicoba } \\
\text { disetujui promotor dan } \\
\text { kopromotor, siap } \\
\text { diujikan pada ujian } \\
\text { kelayakan. }\end{array}$ \\
\hline $\begin{array}{l}\text { Revisi laporan dan } \\
\text { penggandaan setelah } \\
\text { ujian kelayakan }\end{array}$ & $\begin{array}{l}\text { Laporan implementasi } \\
\text { yang sudah diujikan } \\
\text { pada ujian kelayakan, } \\
\text { sudah digandakan. }\end{array}$ & Surabaya & $\begin{array}{l}\text { Laporan implementasi } \\
\text { yang sudah diujikan, } \\
\text { sudah digandakan, } \\
\text { disetujui untuk } \\
\text { diujikan pada ujian } \\
\text { tertutup. }\end{array}$ \\
\hline $\begin{array}{l}\text { Penyusunan draft } \\
\text { disertasi dan } \\
\text { penggandaan }\end{array}$ & $\begin{array}{l}\text { Draft disertasi sudah } \\
\text { digandakan. }\end{array}$ & Singaraja, Bali & $\begin{array}{l}\text { Draft laporan disertasi } \\
\text { disetujui promotor dan } \\
\text { kopromotor, siap } \\
\text { diujikan pada sidang } \\
\text { tertutup. }\end{array}$ \\
\hline $\begin{array}{l}\text { Penggandaan disertasi } \\
\text { yang sudah diujikan } \\
\text { pada ujian tertutup. }\end{array}$ & $\begin{array}{l}\text { Disertasi sudah } \\
\text { digandakan. }\end{array}$ & Surabaya & $\begin{array}{l}\text { Disertasi disetujui } \\
\text { promotor dan } \\
\text { kopromotor, siap } \\
\text { diujikan pada sidang }\end{array}$ \\
\hline
\end{tabular}


Tabel 02. Instrumen Penelitian, Pengumpulan data dan analisis data

\begin{tabular}{|c|c|c|c|c|c|}
\hline No & Tujuan Penelitian & Instrumen & $\begin{array}{c}\text { Sumber } \\
\text { Data }\end{array}$ & $\begin{array}{c}\text { Pengambilan } \\
\text { Data } \\
\end{array}$ & Analisa Data \\
\hline \multirow{3}{*}{1} & \multirow{4}{*}{$\begin{array}{l}\text { Untuk } \\
\text { mendeskripsikan } \\
\text { validitas model } \\
\text { pembelajaran } \\
\text { OPPEMEI yang } \\
\text { dikembangkan untuk } \\
\text { meningkatkan } \\
\text { keterampilan } \\
\text { berpikir kreatif dan } \\
\text { hasil belajar kognitif } \\
\text { melalui matakuliah } \\
\text { konsep dasar IPA }\end{array}$} & $\begin{array}{l}\text { Lembar } \\
\text { Validasi } \\
\text { Pakar }\end{array}$ & Pakar & $\begin{array}{l}\text { Penelahaan dan } \\
\text { penyempurnaan } \\
\text { oleh pakar dan } \\
\text { praktisi }\end{array}$ & $\begin{array}{l}\text { Deskripsi kualitatif } \\
\text { dan analisis statistik } \\
\text { Percentage of } \\
\text { Agreement }\end{array}$ \\
\hline & & $\begin{array}{l}\text { Lembar } \\
\text { Pengamatan } \\
\text { Pengelolaan } \\
\text { Pembelajaran }\end{array}$ & $\begin{array}{l}\text { Dosen dan } \\
\text { Mahasiswa }\end{array}$ & $\begin{array}{l}\text { Observasi yang } \\
\text { dilakukan } 2 \\
\text { orang pengamat }\end{array}$ & $\begin{array}{l}\text { Analisis statistik } \\
\text { deskripsi, yaitu rata- } \\
\text { rata, proporsi dan } \\
\text { persentase }\end{array}$ \\
\hline & & $\begin{array}{l}\text { Lembar } \\
\text { Pengamatan } \\
\text { Aktivitas } \\
\text { mahasiswa }\end{array}$ & Mahasiswa & $\begin{array}{l}\text { Observasi yang } \\
\text { dilakukan } 2 \\
\text { orang pengamat }\end{array}$ & $\begin{array}{l}\text { Analisis statistik } \\
\text { deskripsi, yaitu rata- } \\
\text { rata, proporsi dan } \\
\text { persentase }\end{array}$ \\
\hline \multirow{5}{*}{2} & & $\begin{array}{l}\text { Lembar } \\
\text { Validasi } \\
\text { Rencana } \\
\text { Pelaksanaan } \\
\text { Pembelajaran }\end{array}$ & $\begin{array}{l}\text { Pakar dan } \\
\text { Praktisi }\end{array}$ & $\begin{array}{l}\text { Penelahaan dan } \\
\text { penyempurnaan } \\
\text { oleh pakar dan } \\
\text { praktisi }\end{array}$ & $\begin{array}{l}\text { Analisis statistik } \\
\text { deskripsi, yaitu rata- } \\
\text { rata, proporsi dan } \\
\text { persentase }\end{array}$ \\
\hline & \multirow{4}{*}{$\begin{array}{l}\text { Untuk } \\
\text { mendeskripsikan } \\
\text { validitas perangkat } \\
\text { pembelajaran untuk } \\
\text { mendukung } \\
\text { implementasi model } \\
\text { pembelajaran } \\
\text { OPPEMEI yang } \\
\text { dikembangkan. }\end{array}$} & $\begin{array}{l}\text { Lembar } \\
\text { Validasi Buku } \\
\text { Mahasiswa }\end{array}$ & $\begin{array}{l}\text { Pakar dan } \\
\text { Praktisi }\end{array}$ & $\begin{array}{l}\text { Penelahaan dan } \\
\text { penyempurnaan } \\
\text { oleh pakar dan } \\
\text { praktisi }\end{array}$ & $\begin{array}{l}\text { Analisis statistik } \\
\text { deskripsi, yaitu rata- } \\
\text { rata, proporsi dan } \\
\text { persentase }\end{array}$ \\
\hline & & $\begin{array}{l}\text { Lembar } \\
\text { Validasi } \\
\text { Lembar } \\
\text { Kegiatan } \\
\text { Mahasiswa }\end{array}$ & $\begin{array}{l}\text { Pakar dan } \\
\text { Praktisi }\end{array}$ & $\begin{array}{l}\text { Penelahaan dan } \\
\text { penyempurnaan } \\
\text { oleh pakar dan } \\
\text { praktisi }\end{array}$ & $\begin{array}{l}\text { Analisis statistik } \\
\text { deskripsi, yaitu rata- } \\
\text { rata, proporsi dan } \\
\text { persentase }\end{array}$ \\
\hline & & $\begin{array}{l}\text { Lembar } \\
\text { Validasi Tes } \\
\text { Hasil Belajar }\end{array}$ & $\begin{array}{l}\text { Pakar dan } \\
\text { Praktisi }\end{array}$ & $\begin{array}{l}\text { Penelahaan dan } \\
\text { penyempurnaan } \\
\text { oleh pakar dan } \\
\text { praktisi }\end{array}$ & $\begin{array}{l}\text { Analisis statistik } \\
\text { deskripsi, yaitu rata- } \\
\text { rata, proporsi dan } \\
\text { persentase }\end{array}$ \\
\hline & & $\begin{array}{l}\text { Lembar } \\
\text { Validasi Tes } \\
\text { Berpikir } \\
\text { Kreatif }\end{array}$ & $\begin{array}{l}\text { Pakar dan } \\
\text { Praktisi }\end{array}$ & $\begin{array}{l}\text { Penelahaan dan } \\
\text { penyempurnaan } \\
\text { oleh pakar dan } \\
\text { praktisi }\end{array}$ & $\begin{array}{l}\text { Analisis statistik } \\
\text { deskripsi, yaitu rata- } \\
\text { rata, proporsi dan } \\
\text { persentase }\end{array}$ \\
\hline 3 & $\begin{array}{l}\text { Mendeskripsikan } \\
\text { keterlaksanaan } \\
\text { pembelajaran } \\
\text { dengan model } \\
\text { pembelajaran } \\
\text { OPPEMEI yang } \\
\text { dikembangkan. }\end{array}$ & $\begin{array}{l}\text { Lembar } \\
\text { Pengamatan } \\
\text { Keterlaksana } \\
\text { an SAP }\end{array}$ & $\begin{array}{l}\text { Dosen dan } \\
\text { Mahasiswa }\end{array}$ & $\begin{array}{l}\text { Observasi yang } \\
\text { dilakukan } 2 \\
\text { orang pengamat }\end{array}$ & $\begin{array}{l}\text { Analisis statistik } \\
\text { deskripsi, yaitu rata- } \\
\text { rata, proporsi dan } \\
\text { persentase }\end{array}$ \\
\hline 4 & $\begin{array}{l}\text { Mendeskripsikan } \\
\text { aktivitas mahasiswa } \\
\text { selama diterapkan } \\
\text { model pembelajaran } \\
\text { OPPEMEI yang } \\
\text { dikembangkan. } \\
\text { Mendeskripsikan }\end{array}$ & $\begin{array}{l}\text { Lembar } \\
\text { Pengamatan } \\
\text { Aktivitas } \\
\text { Mahasiswa }\end{array}$ & Mahasiswa & $\begin{array}{l}\text { Observasi yang } \\
\text { dilakukan } 2 \\
\text { orang pengamat }\end{array}$ & $\begin{array}{l}\text { Analisis statistik } \\
\text { deskripsi, yaitu rata- } \\
\text { rata, proporsi dan } \\
\text { persentase }\end{array}$ \\
\hline 5 & $\begin{array}{l}\text { kendala a yang } \\
\text { dihadapi dosen pda } \\
\text { penerapan model } \\
\text { pembelajaran } \\
\text { OPEMEI yang } \\
\text { dikembangkan. }\end{array}$ & $\begin{array}{l}\text { Lembar } \\
\text { Kendala- } \\
\text { kendala } \\
\text { dalam KBM }\end{array}$ & Mahasiswa & $\begin{array}{l}\text { Observasi yang } \\
\text { dilakukan } 2 \\
\text { orang pengamat }\end{array}$ & Deskripsi Kualitatif \\
\hline 6 & Mendeskripsikan & Tes Berpikir & Mahasiswa & Tes berpikir & \\
\hline
\end{tabular}




\begin{tabular}{|c|c|c|c|c|c|}
\hline No & Tujuan Penelitian & Instrumen & $\begin{array}{c}\text { Sumber } \\
\text { Data }\end{array}$ & $\begin{array}{c}\text { Pengambilan } \\
\text { Data }\end{array}$ & Analisa Data \\
\hline & $\begin{array}{l}\text { peningkatan } \\
\text { keterampilan } \\
\text { berpikir kreatif } \\
\text { mahasiswa melalui } \\
\text { penerapan model } \\
\text { pembelajaran } \\
\text { OPPEMEI yang } \\
\text { dikembangkan. } \\
\text { Mendeskripsikan } \\
\text { peningkatan hasil }\end{array}$ & Kreatif & & $\begin{array}{l}\text { kreatif yang } \\
\text { diujikan pada } \\
\text { Mahasiswa }\end{array}$ & Uji N-Gain Score \\
\hline 7 & $\begin{array}{l}\text { belajar kognitif } \\
\text { mahasiswa melalui } \\
\text { penerapan model } \\
\text { pembelajaran } \\
\text { OPPEMEI yang } \\
\text { dikembangkan }\end{array}$ & $\begin{array}{l}\text { Tes hasil } \\
\text { belajar } \\
\text { kognitif }\end{array}$ & Mahasiswa & $\begin{array}{l}\text { Tes hasil belajar } \\
\text { kognitif yang } \\
\text { diujikan pada } \\
\text { Mahasiswa }\end{array}$ & Uji N-Gain Score \\
\hline 8 & $\begin{array}{l}\text { Mendeskripsikan } \\
\text { respon mahasiswa } \\
\text { terhadap } \\
\text { pelaksanaan model } \\
\text { pembelajaran } \\
\text { OPPEMEI yang } \\
\text { dikembangkan }\end{array}$ & $\begin{array}{l}\text { Angket } \\
\text { Respon } \\
\text { Mahasiswa }\end{array}$ & Mahasiswa & $\begin{array}{l}\text { Angket respon } \\
\text { terhadap } \\
\text { kegiatan belajar } \\
\text { mengajar yang } \\
\text { diberikan } \\
\text { kepada } \\
\text { Mahasiswa }\end{array}$ & Deskripsi kualitatif \\
\hline
\end{tabular}

\section{Hasil dan pembahasan}

Perangkat SAP dikembangkan sebagai bentuk operasional model OPPEMEI dalam proses pembelajaran. Komponen perangkat SAP meliputi Silabus, SAP, Buku Ajar Mahasiswa, dan LKM.

\section{Hasil Validitas Rencana Program Semester (RPS)}

Rencana program semester (RPS) merupakan perencanaan proses pembelajaran yang disusun untuk setiap mata kuliah dan disajikan dalam pembelajaran selama satu semester. Perencanaan proses pembelajaran pada RPS berupa kerangka tahap-tahap pembelajaran untuk mencapai kemampuan akhir dengan bahan kajian terkait untuk memenuhi capaian pembelajaran lulusan yang dibebankan pada mata kuliah. RPS yang dikembangkan berdasarkan model OPPEMEI memenuhi kriteria validitas bila skor validasi ahli $\geq 3,41$ atau dengan kriteria minimal valid pada rentang skor 1-5. Percentage of agreement yang menunjukkan konsistensi antar ahli dalam menyatakan kevalidan model OPPEMEI $\geq 75 \%$ atau pada kategori tinggi. Hasil validasi rumusan komponen RPS disajikan pada Tabel 02.

Tabel 02. Hasil Validasi Rencana Pembelajaran Semester (RPS)

\begin{tabular}{|c|c|c|c|c|c|}
\hline \multirow[b]{2}{*}{ No } & \multirow[b]{2}{*}{ Aspek Penilaian } & \multicolumn{2}{|r|}{ Validitas } & \multicolumn{2}{|c|}{ Reliabilitas } \\
\hline & & Skor & Ket & $\mathbf{R}$ & Ket \\
\hline 1 & Identitas RPS & 5.0 & Sangat Valid & $94 \%$ & Reliabel \\
\hline 2 & Deskripsi Matakuliah & 4.3 & Sangat Valid & & \\
\hline \multirow{5}{*}{3} & Capaian Pembelajaran Lulusan & & & & \\
\hline & a. Capaian Pembelajaran Sikap & 5.0 & Sangat Valid & & \\
\hline & b. Capaian Pembelajaran Pengetahuan & 4.7 & Sangat Valid & & \\
\hline & $\begin{array}{l}\text { c. Capaian Pembelajaran Keterampilan } \\
\text { Umum }\end{array}$ & 5.0 & Sangat Valid & & \\
\hline & $\begin{array}{l}\text { d. Capaian Pembelajaran Keterampilan } \\
\text { Khusus }\end{array}$ & 5.0 & Sangat Valid & & \\
\hline 4 & Dibuat Setiap Pertemuan (Minggu ke...) & 4.3 & Sangat Valid & & \\
\hline 5 & Kemampuan Akhir Pembelajaran & 4.7 & Sangat Valid & & \\
\hline
\end{tabular}




\begin{tabular}{llll}
6 & Indikator & 4.3 & Sangat Valid \\
7 & Bahan Kajian & 4.7 & Sangat Valid \\
8 & Pengalaman Belajar & 4.3 & Sangat Valid \\
9 & Penilaian & 5.0 & Sangat Valid \\
10 & Alokasi Waktu & 4.3 & Sangat Valid \\
11 & Referensi & 5.0 & Sangat Valid \\
\hline
\end{tabular}

Tabel 03 menunjukkan bahwa komponen-komponen rencana program semester (RPS) meliputi identitas RPS; capaian pembelajaran lulusan yang dibebankan pada mata kuliah; kemampuan akhir yang direncanakan pada tiap tahap pembelajaran untuk memenuhi capaian pembelajaran lulusan; bahan kajian yang terkait dengan kemampuan yang akan dicapai; waktu yang disediakan untuk mencapai kemampuan pada tiap tahap pembelajaran; pengalaman belajar mahasiswa yang diwujudkan dalam deskripsi tugas yang harus dikerjakan oleh mahasiswa selama satu semester; penilaian; dan daftar referensi yang digunakan telah memenuhi kriteria validitas. Kriteria validitas komponen-komponen RPS secara umum sangat valid. Koefisien reliabilitas percentage of agreement lebih dari 80\%, sehingga tingkat konsistensi antar ahli terhadap keseluruhan aspek validitas konstruk model OPPEMEI sangat tinggi. Hasil analisis validitas RPS menunjukkan ahli sepakat bahwa RPS yang telah dikembangkan berdasarkan model OPPEMEI telah dikonstruksi secara logis dan konsisten, sehingga RPS secara substansi dinilai layak untuk mendukung implementasi model OPPEMEI.

Secara operasional beberapa komponen RPS mengalami revisi. Revisi dilakukan terhadap beberapa komponen dari RPS, sebagaimana tersaji pada Tabel 03. Revisi RPS meliputi komponen-komponen alokasi waktu, konstruksi capaian kemampuan akhir dan penulisan instruksi pembelajaran untuk memberikan pengalaman belajar serta bentuk penilaian ditunjukkan pada tabel 03. Berdasarkan hal tersebut ahli merekomendasikan skala revisi RPS berada pada kriteria skala kecil, sehingga dengan dilakukan revisi tersebut RPS dapat digunakan untuk mengoperasionalkan pembelajaran dengan model OPPEMEI.

Tabel 03. Perbaikan Rencana Program Semester (RPS)

\begin{tabular}{|c|c|}
\hline Komponen RPS & Perbaikan \\
\hline Identitas & $\begin{array}{l}\text { a. Menuliskan kode mata kuliah sesuai dengan kurikulum program } \\
\text { studi. }\end{array}$ \\
\hline \multirow[t]{3}{*}{$\begin{array}{l}\text { Capaian Pembelajaran/ } \\
\text { Kemampuan akhir }\end{array}$} & $\begin{array}{l}\text { a. Capaian pembelajaran dituliskan sebagai rumusan capaian } \\
\text { pembelajaran mata kuliah. }\end{array}$ \\
\hline & $\begin{array}{l}\text { b. Jika memungkinkan rumusan kemampuan akhir dirumsukan } \\
\text { dengan kalimat yang lebih sederhana sehingga mudah diukur. }\end{array}$ \\
\hline & $\begin{array}{l}\text { c. Rumusan indikator hendaknya mengggunakan kata kerja } \\
\text { operasional yang lebih tepat untuk ranah pengetahuan dan } \\
\text { keterampilan. }\end{array}$ \\
\hline \multirow[t]{2}{*}{ Pengalaman belajar } & $\begin{array}{l}\text { a. Rumusan pengalaman belajar dengan kalimat sederhana } \\
\text { sehingga mudah dipahami. }\end{array}$ \\
\hline & b. Kerja kolaboratif hendaknya dinyatakan secara eksplisit. \\
\hline Penilaian & a. Bentuk dan tehnik penilaian dapat divariasikan. \\
\hline
\end{tabular}

\section{Hasil Validasi Satuan Acara Perkuliahan (SAP)}

Perangkat perencanaan proses pembelajaran berupa Satuan Acara Perkuliahan (SAP) merupakan perencanaan pembelajaran secara operasional model OPPEMEI untuk satu kali pertemuan atau lebih yang dikembangkan berdasarkan RPS. Validasi SAP-Model OPPEMEI dilakukan terhadap aspek kesesuaian identitas SAP-Model OPPEMEI, kesesuaian tujuan pembelajaran dengan capaian pembelajaran, relevansi komponen-komponen pembelajaran seperti kemampuan yang hendak dicapai, materi, metode dan penilaian dalam pembelajaran, serta kegiatan pembelajaran dengan model OPPEMEI. SAP-Model OPPEMEI memenuhi kriteria validitas bila skor validasi ahli $\geq 3,41$ atau dengan kriteria minimal valid pada rentang skor 1-5. Selain itu percentage of agreement yang menunjukkan konsistensi antar ahli dalam menyatakan kevalidan model OPPEMEI $\geq 75 \%$ atau pada kategori tinggi. Hasil validasi SAP-Model OPPEMEI disajikan pada Tabel 04. 
Tabel 04. Hasil Validasi Satuan Acara Perkuliahan (SAP)-Model OPPEMEI

\begin{tabular}{|c|c|c|c|c|c|c|c|c|c|}
\hline \multirow{4}{*}{$\begin{array}{l}\text { No } \\
\text { A } \\
1\end{array}$} & \multirow{4}{*}{$\begin{array}{l}\text { Komponen } \\
\text { Identitas SAP } \\
\text { Judul }\end{array}$} & \multicolumn{8}{|c|}{ Topik } \\
\hline & & \multicolumn{2}{|r|}{1} & \multicolumn{2}{|c|}{2} & \multicolumn{2}{|c|}{3} & \multicolumn{2}{|c|}{4} \\
\hline & & \multicolumn{2}{|c|}{ Validitas } & \multicolumn{2}{|c|}{ Validitas } & \multicolumn{2}{|c|}{ Validitas } & \multicolumn{2}{|c|}{ Validitas } \\
\hline & & 4.67 & SV & 4.33 & SV & 4.33 & SV & 5.00 & SV \\
\hline 2 & Jurusan & 5.00 & SV & 4.67 & SV & 5.00 & SV & 5.00 & SV \\
\hline 3 & Program studi & 4.67 & SV & 4.67 & SV & 4.33 & SV & 5.00 & SV \\
\hline 4 & Mata kuliah & 4.67 & SV & 4.33 & SV & 4.67 & SV & 5.00 & SV \\
\hline 5 & Semester & 5.00 & SV & 5.00 & SV & 5.00 & SV & 5.00 & SV \\
\hline 6 & Materi pokok & 4.00 & V & 4.33 & SV & 4.33 & SV & 4.67 & SV \\
\hline 7 & SKS & 5.00 & SV & 4.67 & SV & 5.00 & SV & 5.00 & SV \\
\hline 8 & Pertemuan ke.. & 4.67 & SV & 4.67 & SV & 4.67 & SV & 4.33 & SV \\
\hline B & \multicolumn{9}{|l|}{ Sistematika Isi SAP } \\
\hline 1 & $\begin{array}{l}\text { Konsistensi capaian } \\
\text { pembelajaran mata } \\
\text { kuliah dengan } \\
\text { kemampuan akhir } \\
\text { pembelajaran maupun } \\
\text { indikator }\end{array}$ & 4.33 & SV & 4.33 & SV & 4.67 & SV & 4.67 & SV \\
\hline 2 & $\begin{array}{l}\text { Indikator di SAP sama } \\
\text { dengan indikator di } \\
\text { RPS. }\end{array}$ & 4.67 & SV & 4.67 & SV & 4.33 & SV & 4.67 & SV \\
\hline 3 & $\begin{array}{l}\text { Rumusan indikator } \\
\text { cukup ditulis B-nya } \\
\text { (Behavior) saja (kata } \\
\text { kerja operasional dan } \\
\text { substansinya). }\end{array}$ & 4.33 & SV & 4.67 & SV & 4.33 & SV & 4.33 & SV \\
\hline 4 & $\begin{array}{l}\text { Indikator } \\
\text { diklasifikasikan dalam } \\
\text { ranah kognitif } \\
\text { (Keterampilan berpikir } \\
\text { kreatif dan hasil } \\
\text { belajar) }\end{array}$ & 4.67 & SV & 4.67 & SV & 4.67 & SV & 5.00 & SV \\
\hline 5 & $\begin{array}{l}\text { Materi pembelajaran } \\
\text { (cukup ditulis pokok- } \\
\text { pokok/topik-topik } \\
\text { materi) }\end{array}$ & 4.33 & SV & 4.33 & SV & 4.33 & SV & 4.67 & SV \\
\hline \multirow{4}{*}{6} & $\begin{array}{l}\text { Pendekatan/model/me } \\
\text { tode sesuai indikator. }\end{array}$ & 5.00 & SV & 5.00 & SV & 5.00 & SV & 5.00 & SV \\
\hline & $\begin{array}{l}\text { Media, alat dan bahan } \\
\text { menunjang } \\
\text { ketercapaian indikator. } \\
\text { Langkah-langkah } \\
\text { kegiatan pembelajaran. }\end{array}$ & 4.67 & SV & 4.33 & SV & 4.67 & SV & 5.00 & SV \\
\hline & $\begin{array}{l}\text { Motivasi tidak boleh } \\
\text { hanya verbal (disertai } \\
\text { gambar) }\end{array}$ & 4.67 & SV & 4.67 & SV & 5.00 & SV & 5.00 & SV \\
\hline & $\begin{array}{l}\text { Mencantumkan alokasi } \\
\text { waktu pada kegiatan } \\
\text { pendahuluan, inti, dan } \\
\text { penutup. }\end{array}$ & 5.00 & SV & 4.67 & SV & 5.00 & SV & 5.00 & SV \\
\hline
\end{tabular}




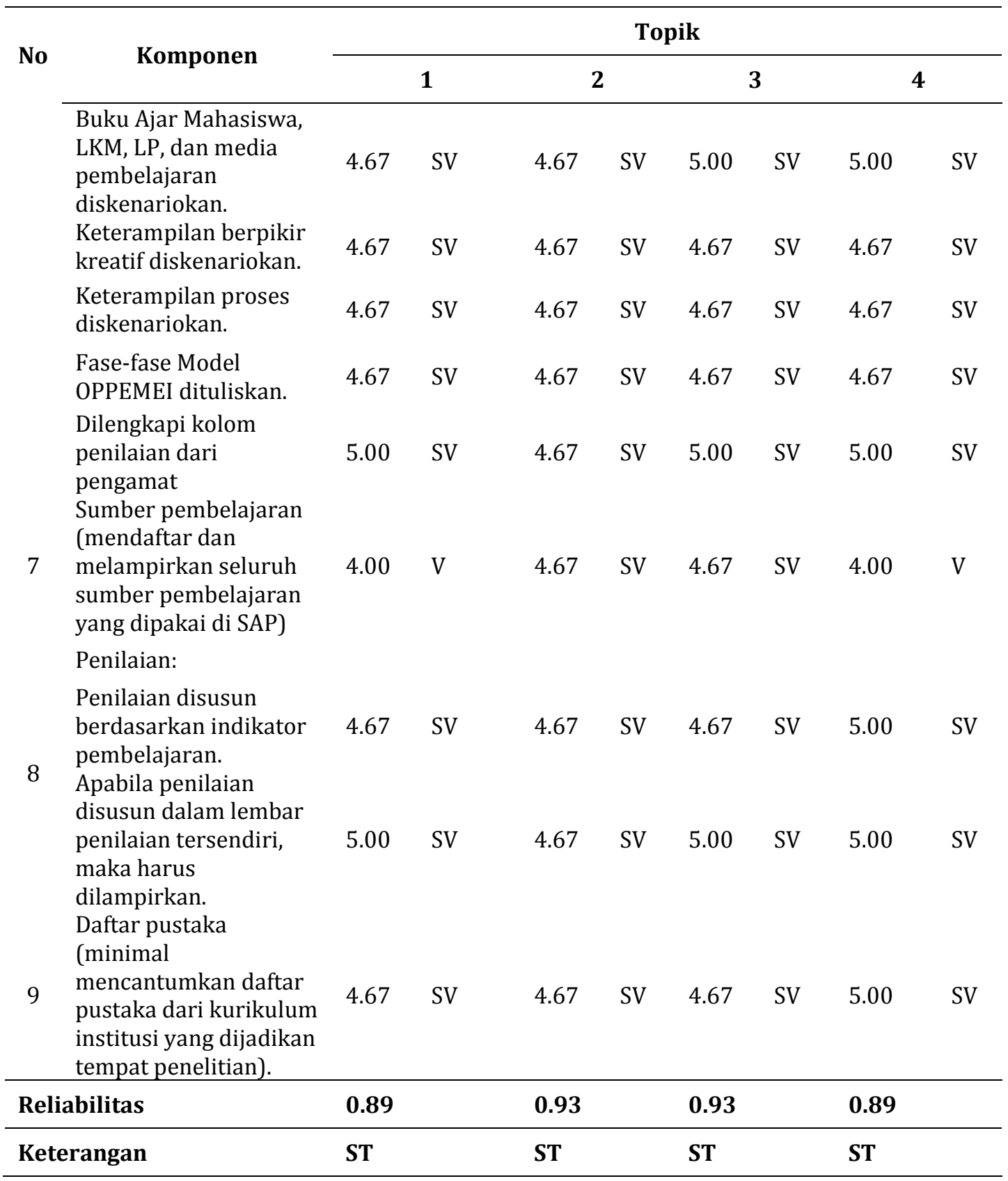

Keterangan : SV : Sangat Valid ; V: Valid; T : Tinggi; ST : Sangat Tinggi

Berdasarkan Tabel 05, kriteria validitas komponen-komponen SAP-Model OPPEMEI secara umum sangat valid. Koefisien reliabilitas percentage of agreement lebih dari $80 \%$, sehingga tingkat konsistensi antar ahli terhadap keseluruhan komponen SAP-Model OPPEMEI sangat tinggi. Hal tersebut mengindikasikan ahli sepakat bahwa SAP-Model OPPEMEI yang telah dikembangkan layak sebagai pendukung implementasi model OPPEMEI. Saran yang disampaikan oleh validator ditindaklanjuti untuk perbaikan perangkat perencanaan pembelajaran SAP-Model OPPEMEI. Secara umum saran perbaikan meliputi konsistensi dalam penggunaan istilah seperti skenario pembelajaran dengan langkah-langkah pembelajaran, bahan kajian dengan materi. Perbaikan terkait dengan komponen-komponen SAP-Model OPPEMEI disajikan pada Tabel 05.

Tabel 05. Perbaikan Satuan Acara Perkuliahan (SAP)-Model OPPEMEI

\begin{tabular}{ll}
\hline \multicolumn{1}{c}{ Komponen SAP } & \multicolumn{1}{c}{ Perbaikan } \\
\hline Identitas & Pengalokasian waktu merujuk pada ketentuan yang berlaku seperti \\
& Permenristek Dikti nomor 44 tahun 2015. \\
Tujuan Pembelajaran & Penomoran tujuan pembelajaran disesuaikan capaian pembelajaran
\end{tabular}


Media dan Sumber Belajar Kegiatan pembelajaran untuk pengetahuan maupun keterampilan.

Buku penunjang sebagai sumber belajar dituliskan judulnya.

Alokasi waktu yang digunakan pada setiap langkah pembelajaran dikaji lagi kesuaian dengan aktifitas pembelajaran Rancangan penilaian telah baik, tetapi perlu dipertimbangkan

Penilaian

Berdasarkan hasil penelitian yang sudah dijabarkan sebelumnya, diperoleh bahwa perangkat pembelajaran berupa RPS dan SAP yang dikembangkan berdasarkan model OPPEMEI dikatakan layak bahkan berada pada katagori sangat baik berdasarkan uji Validasinya. Hasil analisis validitas RPS menunjukkan ahli sepakat bahwa RPS yang telah dikembangkan berdasarkan model OPPEMEI telah dikonstruksi secara logis dan konsisten, sehingga RPS dan SAP secara substansi dinilai layak untuk mendukung implementasi model OPPEMEI. Perangkat pembelajaran adalah pedoman yang digunakan oleh pendidik dalam pelaksanaan proses pembelajaran. Perangkat pembelajararan sangat membatu dalam melaksanakan proses pembelajaran. menurut Borich (2007) dalam (Veryliana \& Wangid, 2016) menyatakan bahwa rancangan adalah proses yang sistematis apa dan bagaimana siswa belajar. Menurut Remi (2016) perangkat pembelajaran adalah sekumpulan sumber belajar yang membantu guru dan siswa melakukan proses belajar.Kualitas perangkat pembelajaran ini terlihat dari komponen-komponen yang terdapat didalamnya yang sudah menggambarkan bagaimana proses pembelajarannya dan apa tujuan dari pembelajaran yang dirancang atau deprogram yaitu mahasiswa mampu mengembangakan kemapuan berfikir kritisnya. Selain itu perangkat pembelajaran yang dikembangkan sudah valid ini terlihat dari hasil penelitian yang dilakukan, serta perangkat pembelajaran juga sudah praktis ini dapat dilihat darisemua aspek atau komponen sudah ada selain itu juga proses pembelajaran berlajar dengan baik dan tujuan dari pembelajaran tercapai. Serta Prangkat pembelajaran sudah efektif hal ini dapat dilihat dari peningkatan kemapuan berpikir kreatif perserta didik yang berdampak pada hasil belajarnya.

Kemampuan berpikir kreatif mengacu pada sebuah konsep dari aktivitas mental untuk membuat hubungan-hubungan (conections) yang terus menerus (kontinu), sehingga dihasilkan produk assosiasi berpikir yang tepat (Evans, 1991), yang pada prnsipnya adalah sejalan dengan hal tersebut di atas Utami (2009) dan Guilford (1981) menjelaskan bahwa keterampilan berpikir kreatif meliputi lima aspek kreatif yaitu kelancaran (fluency), keluwesan (flexibility), keaslian (originality), merinci (elaboration) dan menilai (evaluation) dengan penjelasan sebagai berikut: (1) Kelancaran berpikir (fluency of thinking). Pada aspek itu, maka kelancaran adalah kemampuan untuk menghasilkan banyak ide yang keluar dari pemikiran seseorang secara cepat. Dalam kelancaran berpikir, yang ditekankan adalah kuantitas bukan kualitas. Lebih lanjut, keluwesan berpikir (flexibility), adalah kemampuan untuk memproduksi sejumlah ide, jawaban-jawaban atau pertanyaan-pertanyaan yang bervariasi, dapat melihat suatu masalah dari sudut pandang yang berbeda-beda, mencari alternatif atau arah. Keluwesan berpikir adalah kemampuan untuk memproduksi sejumlah ide, jawaban-jawaban atau pertanyaan-pertanyaan yang bervariasi, dapat melihat suatu masalah dari sudut pandang yang berbeda-beda, mencari alternatif atau arah yang berbeda-beda, serta mampu menggunakan bermacam-macam pendekatan atau cara pemikiran. Orang yang kreatif adalah orang yang luwes dalam berpikir. Peserta didik dengan mudah dapat meninggalkan cara berpikir lama dan menggantikannya dengan cara berpikir yang baru, berpikir luwes menyediakan ruang untuk perubahan ide-ide dan berpikir untuk memasukkan berbagai sudut pandang, berbagai pendekatan berbeda dari sebuah solusi. Selain itu, komponen berpikir kreatif adalah keaslian (originality). Keaslian merupakan kemampuan untuk mencetuskan gagasan unik atau kemampuan untuk mencetuskan gagasan asli. Keaslian berkaitan dengan kemampuan memberikan sesuatu yang kas atau unik yang berbeda dari yang lainnya. Keaslian adalah kemampuan untuk membuat kombinasi-kombinasi yang unik dari suatu pemecahan masalah. Keaslian ide digambarkan sebagai sesuatu hal yang unik mengejutkan, tidak biasa, tidak konvensional, aneh, dan luar biasa. Aspek merinci (elaboration) pada berpikir kreatif dititik beratkan pada kemampuan dalam mengembangkan gagasan dan menambahkan atau memperinci detaildetail dari suatu objek, gagasan atau situasi sehingga menjadi lebih menarik. Dapat juga dikatakan elaborasi merupakan penambahan detail atau keterangan terhadap ide yang sudah ada. Aspek terakhir yang menjadi titik kritis berpikir kreatif adalah evaluasi (evaluation). Aspek evaluasi merupakan kemampuan untuk mengambil keputusan terhadap situasi yang terbuka. Evaluasi dalam memecahkan suatu masalah tidak hanya mencetuskan gagasan tetapi juga harus melaksanakannya dengan arif dan bijaksana. Perangkat pembelajaran yang di kembangkan yang mengacu kepada model OPPEMEI sudah nampak dalam langkah atau sintak perangkatat pembelajarannya.

Pembelajaran OPPEMEI diekstrak dari tiga model pembelajaran inovatif berpusat pada mahasiswa seperti PBL, BBL dan inquiri. Formulasi berpikir kreatif peserta didik merupakan inti yang dikembangkan 
dari model OPPEMEI. Kondisi ini didasari bahwa model pembelajaran untuk sains selalu berangkat pada model pembelajaran 5M (Mengamati, Menanya, Mencoba, Menalar, dan Mengkomunikasikan). Oleh karena Model pembelajaran yang mampu menghasilkan berpikir kreatif sesungguhnya adalah penerapan pendekatan pembelajaran saintifik, meniscayakan kehadiran guru yang tidak saja sabar dan telaten, tetapi juga cerdas dan kreatif berkolaborasi dengan peserta didik untuk menciptakan kondisi pembelajaran yang memunginkan mereka mampu merumuskan masalah dengan baik. Para guru/dosen diharapkan mampu menfasilitasi peserta didik berlatih berfikir analitis, bukan berpikir mekanis.

Pendekatan saintif juga terlihat pada tahapan Model OPPEMEI yang terdiri : (1) orientasi, (2) penggalian ide kreatif, (3) penyelidikan (investigasi), (4) elaborasi, (5) menyajikan hasil karya, (6) evaluasi, dan (7) implementasi. Penggunaan model ini berangkat dari teori motivasi kognisi, teori ini percaya bahwa individu terdorong untuk melaksanakan tindakan dari pemikirannya bila diberikan stimulus dengan berbagai problem yang kontekstual, sehingga terkonstruksi pemahaman yang lebih mendalam. Selain itu kontruksi keterampilan berpikir kreatif juga dapat dimunculkan dengan baik.

Pada fase orientasi, mahasiswa dituntut dan dikondisikan untuk memiliki kemampuan berpikir lancar (fluency), sehingga terfokus dan dapat meningkatkan rasa ingin tahu dan senang dalam memecahkan masalah sains. Berpikir lancar dapat diinisiasi dalam dua persoalan, yaitu isyarat kelancaran digunakan untuk memantau awal: kelancaran menjawab, atau kecepatan yang menghasilkan jawaban awal, intuitif (Thompson, Turner, \& Pennycook, 2011), dan kelancaran perseptual, atau kemudahan masalah yang dapat dibaca (Alter, Oppenheimer, Epley, \& Eyre, 2007, dalam Thompson et al., 2011). Solusi kelebihan fase orientasi dibandingkan dengan model trivial awalnya adalah pada aspek pemberian contoh lebih sederhana, untuk menyerderhanakan permasalahan.

Fase kedua, penggalian ide kreatif; mahasiswa pada fase ini menggali ide-ide kreatif dalam memecahkan masalah dengan membuat rumusan masalah, rumusan hipotesis, menentukan variabel, definisi varibel, dan merancang prosedur eksperimen. Mahasiswa dapat belajar secara optimal, bila dosen memberikan motivasi intrinsik secara tepat (Chin \& Siew, 2015). Peserta didik diberikan masalah bersifat ambivalensi/ill structure, maka akan meningkatkan rasa ingin tahu (Arends, 2012). Solusi dari mengatasi kelemahan pada model BBL, PBL dan Inkuiri, pada fase ini mahasiswa dapat membangun konsep belajar terintegrasi dan pemahaman yang menyeluruh.

Fase ketiga, penyelidikan/investigasi. Dosen mendampingi mahasiswa melakukan penyelidikan/investigasi sesuai dengan desain rancangan yang telah ditetapkan. Mendampingi mahasiswa untuk mengklasifikasikan data dan fakta yang diperoleh secara runtut. Solusi yang diperbaiki adalah mahasiswa dapat menetukan cara yang paling baik dalam pemecahan masalah sains dalam kelompok yang tidak besar. Mahasiswa memiliki pikiran terbuka terhadap berbagai situasi serta mampu membuat gambaran mental terhadap masalah yang dihadapi.

Fase keempat, elaborasi, mengembangkan dan memperluas suatu gagasan baru (originalitas), memperinci detail-detail pemecahan masalah dan argumentasi ilmiah yang termuat dalam laporan hasil penyelidikan. Dukungan Empiris Penyediaan lingkungan belajar yang sesuai dengan kebutuhan anak didik (Amabile \& Hennessey, 1992; Hasirci \& Demirkan, 2003). Solusi dalam mengatasi kelamahan pada model PBL, BBL dan inkuiri, yaitu dengan modifikasi pada fase elaborasi dengan meningkatkan nilai kerjasama, kegiatan memberikan waktu lenih lama engan karakter kelompok yang bersifat heterogen. Pada aspek pemecahan masalah diberikan lebih rinci, sehingga mampu meningkatkan berpikir tingkat tinggi pada peserta didik.

Fase kelima, menyajikan hasil karya, mahasiswa mampu berpikir lancar untuk menghasilkan banyak gagasan/jawaban yang relevan dengan permasalahan sains yang diberikan dan memiliki kemampuan berpikir yang luwes untuk mempertahankan dan menerima pendapat. Mahasiswa mampu mengungkapkan gagasan/gambaran pengalaman hasil penyelidikan secara rinci. Solusi yang diberikan pada fase ini, yakni membutuhkan pedampingan dengan managemen waktu yang ketat. Mahasiswa mampu dengan lancar mempersentasikan hasil penyelidikannya.

Fase keenam evaluasi, pada fase ini mahasiswa dapat menilai situasi yang berkaitan dengan pemecahan masalah. Mahasiswa mampu mengevaluasi hasil pembelajaran secara proses dan produk. Solusi yang ditawarkan. Membutuhkan rubrik untuk penilaian, Dapat menjadi inspirasi bagi IQ Tinggi dan Rendah.

Fase ketujuh implemetasi, mahasiswa mampu secara originalitas menerapkan teori/konsep untuk menghasilkan produk kreatif, serta mahasiswa mampu reflex (evaluasi) dan penilaian akhir atas keterampilan berpikir kreatif, sehingga mahasiswa mendapatkan pengetahuan yang signifikan. Solusi yang sodorkan pada fase ini, yaitu dibutuhkan pengajar yang mampu mengimplementasikan ide-ide yang baru dalam kehidupan sehari-hari. Mengoptimalkan penguasaan konsep dan kemampuan berpikir kreatif, sehingga melahirkan rasa senang dan mencintai proses belajar. 
Kebaruan model OPPEMEI dibandingkan model pembelajaran model Inovatif dan kreatif lainnya adalah (1) dapat membangun kemampuan untuk berpikir lancar (fluency), sehingga terfokus dan meningkatkan rasa ingin tahu dan senang dalam memecahkan masalah sains, (2) Peserta didik dapat memiliki motivasi intrinsik secara tepat serta rasa percaya diri dalam proses pembelajaran, (3) Membangun cara berpikir original (asli) dalam menyelidiki suatu permasalahan, sehingga mudah merumuskan hipotesis serta pikiran terbuka terhadap berbagai situasi serta mampu membuat gambaran mental terhadap masalah yang dihadapi, (4) Mengembangkan dan memperluas suatu gagasan baru (originalitas), serta dapat menjelaskan secara rinci /mendetail serta mampu memberikan argumentasi ilmiah dengan mengkonstruksi teori dari berbagai sumber pengetahuan, (5) Mahasiswa memiliki kemampuan berpikir yang luwes untuk mempertahankan dan menerima pendapat. (6) Mahasiswa mampu mengoptimal penguasaan konsep dan kemampuan berpikir kreatif nya, sehingga melahirkan rasa senang dan mencintai proses belajar pada diri mahasiswa. (7) Mahasiswa mampu menilai dan membuat masalah baru setelah melaksanankan pembelajaran.

Berdasarkan hasil penelitian penjabaran tentang model OPPEMEI dapat dikatakan bahwa perangkat pembelajaran yang dikembangkan dengan Model OPPEMEI sudah menunjukkan hasil validasi yang baik serta bisa digunakan karena sudah menunjukkan perangkat pembelajaran yang berkualitas yaitu dengan nilai validitas yang tinggi, Nilai kepraktisan serta menunjukkan nilai yang efesien ini nanpak dari proses pembelajaran berjalan dengan baik serta langkah-langkahnya sudah mendukung tercapainya pengembangan berpikir Kreatif.

\section{Simpulan dan saran}

Berangkat dari hasil pembahasan di atas maka dapat disimpulkan bahwa: (1) Kriteria validitas komponen-komponen RPS secara umum sangat valid. Koefisien reliabilitas percentage of agreement lebih dari 80\%, (94\%) sehingga tingkat konsistensi antar ahli terhadap keseluruhan aspek validitas konstruk model OPPEMEI sangat tinggi. Hasil analisis validitas RPS menunjukkan ahli sepakat bahwa RPS yang telah dikembangkan berdasarkan model OPPEMEI telah dikonstruksi secara logis dan konsisten, sehingga RPS secara substansi dinilai layak untuk mendukung implementasi model OPPEMEI. (2) kriteria validitas komponen-komponen SAP-Model OPPEMEI secara umum sangat valid. Koefisien reliabilitas untuk topik I, II, III dan IV, berturut-turut 0, 89; 93; 0,93, dan 0,89 sehingga tingkat konsistensi antar ahli terhadap keseluruhan komponen SAP-Model OPPEMEI sangat tinggi. Hal tersebut mengindikasikan ahli sepakat bahwa SAP-Model OPPEMEI yang telah dikembangkan layak sebagai pendukung implementasi model OPPEMEI

Berangkat hasil temuan penelitian ini dapat disarankan bahwa perlu dilakukan uji terbatas dan uji skala besar terhadap perankap pembelajaran yang dihasilkan, sehingga dapat menghasilkan kompetensi yang diharapkan.

\section{Daftar Rujukan}

Agustiana, T. I. G. A. (2015). Model Pembelajaran OPEMES dalam meningkatkan Keterampilan Berpikir Kreatif Mahasiswa PGSD. Surabaya.

Amabile, T. M., \& Hennessey, B. A. (1992). The motivation for creativity in children.

Arends, R. I. (2012). Learning to Teach. New York: McGraw-Hill Companies.

Caine, R. N. C., \& G. (1945). Reinventing Schools Through Brain-Based Learning. Educational Leadership, 43-47.

Chin, M. K., \& Siew, N. M. (2015). The development and validation of a figural scientific creativity test for preschool pupils. Creative Education, 6(1), 1391-1402.

Connell, J. D. (2009). The Global Aspects of Brain-Based Learning'. Educational Horizons, 88(1), 28-39.

Fauziah, Y. N. (2011). Analisis kemampuan guru dalam mengembangkan keterampilan berpikir kreatif siswa Sekolah Dasar kelas V pada pembelajaran Ilmu Pengetahuan Alam. Jurnal Edisi Khusus, 1(1), 98-106.

Fazilla, S. (2016). Pengembangan Kemampuan Afektif Mahasiswa PGSD Dengan Menggunakan Bahan Ajar Lembar Kerja Mahasiswa (Lkm) Dalam Pembelajaran IPA Di Universitas Almuslim. Jurnal Pendidikan 
Dasar (JUPENDAS), 1(2).

Graaff, E. D. E., \& Kolmos, A. (2003). Characteristics of Problem-Based Learning. Int J Engng Ed, 19(5), 657662. https://doi.org/0949-149X/91

Hasirci, D., \& Demirkan, H. (2003). Creativity in Learning Environments: The Case of Two Sixth Grade Art-Rooms. The Journal of Creative Behavior, 37(1), 17-41.

Holaday, S. D., \& Buckley, K. M. (2008). Addressing challenges in nursing education through a clinical instruction model based on a hybrid, inquiry-based learning framework. Nursing Education Perspectives, 29, 353-358.

Jones, R. (2006). Problem-based learning: description, advantages, disadvantages, scenarios and facilitation. Anaesth Intensive Care, 34, 485-488.

Laksana, D. N. L. (2016). Miskonsepsi Dalam Materi IPA Sekolah Dasar. JPI (Jurnal Pendidikan Indonesia), $5(2), 166-175$.

Lam, D. (2004). Problem-Based Learning: an Integration of Theory and Field. Journal of Social Work Education, 40, 371-389. https://doi.org/10.2307/23043989

Mastropieri, Margo, A., Thomas, E. S. R. ., \& Carter, B. K. (2001). Correlates Of Inquiry Learning Of Science: Constructing Concepts Of Density And Buoyancy. Journal Remedial and Special Education, 22(1), 130-137.

McParland M, Noble LM, L. G. (2004). The effectiveness of problem-based learning compared with traditional teaching in undergraduate psychiatry. Med Educ, 38, 859-867.

Osgood-Campbell, E. (2015). Investigating the educational implications of embodied cognition: A model interdisciplinary inquiry in mind, brain, and education curricula. Mind, Brain, and Education, 9(1), 39. https://doi.org/10.1111/mbe.12063

Pamungkas, A. S. (2017). Pengembangan Bahan Ajar Berbasis Literasi pada Materi Bilangan bagi Mahasiswa Calon Guru SD. JPsd (Jurnal Pendidikan Sekolah Dasar), 3(2), 228-240.

PISA, 2013. (2012). What Student and Can Do-Student Performance in Reading, Matemathetics and Science. Retrieved July 18, 2010, from OECD website: http://dx.doi.org/10.1787/9789264201118en

Purwandari, M. S., Suharmini, T., Si, M., \& Ayriza, Y. (2013). Belajar dan Faktor-faktor yang Mempengaruhinya.

Rahayu, Y. S., Susantini, E., \& Asmara, R. (2015). Biologi Berorientasi Pendekatan TASC (Thinking Actively In Social Conteks) Untuk Melatihkan Keterampilan Berpikir Kreatif Siswa. Pendidikan Sains Pascasarjana Universitas Negeri Surabaya, 5(1), 885-890.

Remi, A. R. (2016). Pengembangan Perangkat Pembelajaran Dalam Implementasi Strategi Contextual Teaching Learning Untuk Meningkatkan Hasil Belajar Ips Pokok Bahasan Perkembangan Teknologi. Jurnal Pendidikan, 1(1), 1-11. Retrieved from https://journal.unesa.ac.id/index.php/jp/article/view/362/195

Rustaman, N. Y. (2005). Perkembangan penelitian pembelajaran berbasis inkuiri dalam pendidikan sains. In Makalah dipresentasikan dalam Seminar Nasional II Himpunan Ikatan Sarjada dan Pemerhati Pendidikan IPA Idonesia Bekerjasama dengan FPMIPA. Bandung.

Samatowa, U. (2006). Hakikat Pembelajaran IPA SD. Jakarta: Indeks.

Suhandi, A., Samsudin, A., \& Hermita, N. (2018). Effectiveness of the use of question-driven levels of inquiry based instruction (QD-LOIBI) assisted visual multimedia supported teaching material on enhancing scientific explanation ability senior high school students. In Journal of Physics: Conference Series, 1013(1), 12026.

Sulistyaningrum, H., Winata, A., \& Cacik, S. (2019). Analisis Kemampuan Awal 21st Century Skills Mahasiswa Calon Guru SD. Jurnal Pendidikan Dasar Nusantara, 5(1), 142-158.

Talib, A., \& Kailani, B. (2014). Problem Based Learning in Cooperative Situation (PBLCS) and Its Impact on Development of Personal Intelligence. International Journal of Evaluation and Research in Education, $3(4)$,

from 
http://search.ebscohost.com/login.aspx?direct=true\&db=eric\&AN=EJ1091689\&site=ehost-live

Tan, O. S. (2003). Enhancing Thinking through Problem-based Learning Approaches. Singapore: Cengage Learning.

Thompson, V. A., Turner, J. A. P., \& Pennycook, G. (2011). Intuition, reason, and metacognition. Cognitive Psychology, 63(3), 107-140.

Utami, M. (2009). Pengembangan Kreativitas Anak Berbakat. Jakarta: PT Gramedia Utama.

Veryliana, P., \& Wangid, M. N. (2016). Pengembangan Perangkat Pembelajaran Berbasis Scientific Approach Untuk Membangun Karakter Kepedulian Dan Kedisiplinan. Jurnal Pendidikan Karakter, $\begin{array}{lrr}V I(2), & 167-180 . & \text { Retrieved }\end{array}$ https://journal.uny.ac.id/index.php/jpka/article/viewFile/12047/8607

Zhang, X., Wang, D., \& Wang, T. (2016). Inspiration or Preparation? Explaining Creativity in Scientific Enterprise. 741-750. https://doi.org/10.1145/2983323.2983820 